\title{
Dandie Dinmont Terrier
}

National Cancer Institute

\section{Source}

National Cancer Institute. Dandie Dinmont Terrier. NCI Thesaurus. Code C53716.

The Dandie Dinmont Terrier is longer than he is tall with short and muscular legs. The solid head is covered with a distinctive topknot. The unique crisp-textured coat contains a mixture of harsh and soft hair. It comes in two colors, pepper or mustard. The topknot and furnishings on pepper Dandies are silver and on mustard Dandies are cream colored. Height: 8-11 inches (20-28 cm.) Weight: 18-24 pounds (8-11 kg.) 